The localization of

\section{plastic deformation in bimetal}

YuLIA V. LI - Institute of Strength Physics and Materials Science - jul2207@mail.ru

SvetlanA A. BARANNIKOVA - Institute of Strength Physics and Materials Science - bsa@ispms.tsc.ru

LEV B. ZUEV - Institute of Strength Physics and Materials Science - Ibz@ispms.tsc.ru

Érkezett: 2018. 06. 22. - Received: 22. 06. 2018. - https://doi.org/10.14382/epitoanyag-jsbcm.2018.30

\section{Abstract}

Plastic flow localization patterns in bimetal laminates at the macroscale level have been researched. It has been found that plastic deformation proceeds during the whole process of deformation and localized in base, transition and cladding layer of bimetal. Kinetics of proliferation of plastic deformation localization fronts has been traced at different stages of the curve demonstrating plastic flow in A 283 Grade +301 AISI bimetal composed of 301 AISI austenitic stainless steel and A 283 Grade low-carbon steel. Staging of deformation curves has been analyzed.

Keywords: bimetal, localization of the plastic deformation, DESP, plastic flow, autowaves

Kulcsszavak: bimetál, képlékeny alakváltozás lokalizálása, DESP, képlékeny folyás, autohullámok
Li Yulya VLADIMIROVNA

post-graduate student of the Laboratory of Strength Physics in the Institute of Strength Physics and Materials Science SB RAS (ISPMS).

Barannikova Svetlana ALEKSANDROVNA

Doctor of Physical and Mathematical Sciences, leading Scientific worker of the Laboratory of Strength Physics in the Institute of Strength Physics and Materials Science SB RAS (ISPMS).

Zuev Lev BORISOVICH Doctor of Physical and Mathematical Sciences, Head of the Laboratory of Strength Physics in the Institute of Strength Physics and Materials Science SB RAS (ISPMS).

\section{Introduction}

In recent decades, studies of the plastic deformation localization at the macroscale level have been one of the most complex problems related to the plastic flow of materials. Experimental studies of plastic deformation localization $[1,2]$ conducted using the double-exposure speckle photography (DESP) method [3,4] and digital image correlation (DIC) method [5] showed that plastic deformation is localized within the whole deformation process for different types of materials with FCC, BCC and HCP lattice.

Different forms of plastic deformation localization at the macroscale level can be considered as different types of autowaves depending on applicable strain hardening law [6,7].

There are lots of examples of plastic deformation localization at the macroscale level. First of all, well-known studies of localized deformation fronts by Chernov and Lüders [8 - 10] should be recalled. They initiated the modern approach to study of plastic flow. Such a band typical for deformation of several alloys [11] in the yield plateau is a front of plastic deformation moving from on machine grip to another. These bands are often visible to the unaided eye on the preliminary polished surface of a metal specimen. Fronts separate from each other areas of elastic (more exactly, microflow) and plastic deformation.

At present, there is growing interest in studies of deformation behaviour of multilayer materials in the course of severe plastic deformation. These materials can be made by combining dissimilar metals into a solid composite, which preserves reliable bonding of components during further processing and under operation conditions. These materials include twolayer metal composites, namely, bimetals, including corrosion resistant bimetals, which are quite resistant to exposure of corrosive media and have excellent mechanical properties [1216].

It is known that diffusion processes occur during manufacturing of bimetals in the course of joint hot rolling of dissimilar layers and further process heating. These processes are found in the interface area of materials, and they form transition areas, which are chemically and structurally inhomogeneous. Nature of occurrence and propagation of plastic deformation localization fronts in base, transition and cladding layers of bimetal differs from the nature of front propagation in a single-layer material. In this connection, it is necessary to improve knowledge on the processes of joining dissimilar metals and their joint deformation on micro-, mesoand macroscale levels.

\section{Materials and methods}

Bimetal samples, cut from the strip, produced according to the following procedure, were studied: A 283 Grade steel (backing metal) was poured between the sheets of 301 AISI cladding metal put into the mold box $-\left(\mathrm{T}=1500^{\circ} \mathrm{C}\right)$ followed by hot rolling of a produced three-layer sheet at $\mathrm{T}=1200 \div 1400^{\circ} \mathrm{C}$. Along the outer edge of the specimen, on both sides, a cladding layer approximately $750 \mu \mathrm{m}$ thick made of 301 AISI steel is provided, and in the center - a base metal layer approximately $6.7 \mathrm{~mm}$ thick made of A 283 Grade steel is provided.

Mechanical uniaxial tensile tests were conducted at $\mathrm{T}=300 \mathrm{~K}$ at deformation velocity of $6.67 \times 10^{-5} \mathrm{~s}^{-1}$ using testing machine LFM-125.

Detailed research of plastic flow localization patterns at the microscale level was conducted using multipurpose measuring complex ALMEC-tv designed for digital registration of fields of displacement vectors and tensor component of plastic distortion [3]. Using this complex, the tensile sample was illuminated with coherent light of a semiconductor laser with a wavelength of $635 \mathrm{~nm}$ and a power of $15 \mathrm{~mW}$. Obtained images of the deformed sample superimposed with speckle patterns were recorded with PixelLink PL-B781 digital video camera. A count sequence for each image point was formed characterizing the time course of its brightness; dispersion and expectation for speckle flicker brightness were calculated, which were used for mapping plastic deformation localizations. This method allowed in situ recording of areas, where deformation of material is localized at the specified growth of sample length. 


\begin{tabular}{|c|c|c|c|c|c|c|c|c|c|c|c|c|}
\hline \multirow{2}{*}{ Bimetal } & \multirow{2}{*}{250} & \multirow{2}{*}{421} & \multirow{2}{*}{27.2} & $\mathrm{n}$ & $\varepsilon_{\mathrm{n}}$ & $\varepsilon_{\mathrm{k}}$ & $\mathrm{n}$ & $\varepsilon_{\mathrm{n}}$ & $\varepsilon_{\mathrm{k}}$ & $\mathrm{n}$ & $\varepsilon_{\mathrm{n}}$ & $\varepsilon_{\mathrm{k}}$ \\
\hline & & & & 1 & - & - & 0.5 & 0.09 & 0.20 & 0.3 & - & - \\
\hline A 283 Grade & 262.7 & 391.92 & 28 & 1 & - & - & 0.5 & 0.15 & 0.23 & 0.3 & - & - \\
\hline \multirow[b]{2}{*}{301 AISI } & \multirow{2}{*}{247} & \multirow{2}{*}{812} & \multirow{2}{*}{73} & 1 & 0.04 & 0.13 & \multirow{2}{*}{0.5} & \multirow[b]{2}{*}{-} & \multirow[b]{2}{*}{-} & \multirow{2}{*}{0.3} & \multirow[b]{2}{*}{ - } & \multirow[b]{2}{*}{-} \\
\hline & & & & 1 & 0.14 & 0.68 & & & & & & \\
\hline
\end{tabular}

Table 1. Mechanical properties of materials

1. táblázat Azanyagok mechanikai jellemzői

\section{Result and discussion}

Tensile diagrams of flat bimetal sample as well as diagrams of similar samples made of A 283 Grade and 301 AISI steel are shown in Fig. 1. They cover the area of elastic and plastic deformations and degradation.

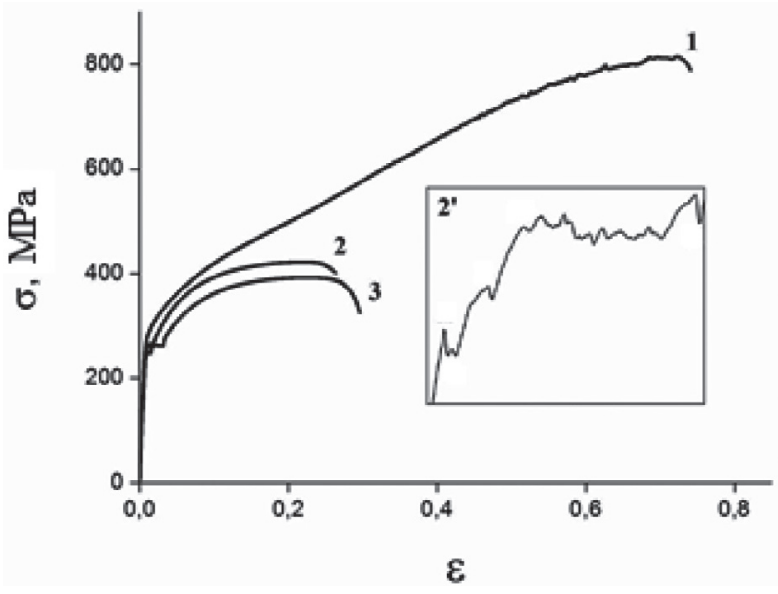

Fig. 1. Stress-strain diagrams: 1 - 301 AISI; 2 - bimetal; 3 - A 283 Grade; 2 -yield plateau of curve 2 for bimetal

1. ábra Feszültség-alakváltozás diagramok: 1 - 301 AISI; 2 - bimetál; 3 - A 283 acél; 2 -folyási határ a 2 - bimetál görbéhez

Bimetal curve downstream of the yield plateau in the area of plastic deformation is located between curves for its components (20 samples of each metal were tested). Loading diagrams of A 283 Grade steel and bimetal show clearly marked yield drop and yield plateau, where oscillations of stress are visible (Fig. 1). Cladding layer of stainless steel provides reduction of yield plateau propagation, improvement of tensile strength and reduction of plasticity of base metal (A 283 Grade steel). For complete coverage of occurrence and propagation of Chernov-Lüders bands (CLBs) in bimetal, registration of speckle image during experiments started when stress was lower that the value of yield strength and stopped when the yield plateau was ended and during transition to the stage of strain hardening.

Analysis of plastic yielding curves of materials (Fig. 1) showed that diagrams are related to the general type diagrams. Bonding between deformations and stress is reasonable to demonstrate using Ludwick equation

$\sigma(\varepsilon)=\sigma_{y}+\theta \varepsilon^{n}$

where $\varepsilon$ and $\sigma$ - current stress and deformation, $\sigma_{\mathrm{y}}-$ yield strength, $\theta$ - deformation hardening factor; $\mathrm{n} \leq 1$ - deformation hardening index. Application of Ludwick equation and presentation of loading curve in coordinates $\ln \left(s-s_{0}\right)=f(\ln e)$ allow for defining stages in deformation curves, where index $\mathrm{n}$ is constant and changes discretely from section to section, where $s$ - true stress disregarding changes in cross section of an operating part during uniaxial tension, $\mathrm{MPa} ; e$ - true strain.

Analysis of loading curve staging revealed the following stages of plastic flow:

1. In A 283 Grade steel, downstream of the transition section from the elastic part to plastic flow at total deformation $\varepsilon_{\text {tot }}=0.008-0.03$ a yield plateau is observed; then, at total deformation $\varepsilon_{\text {tot }}=0.15-0.23$ the stage of parabolic deformation hardening is found with total length $\varepsilon_{\text {tot }}=0.08$. Stages of linear deformation hardening and predegradation are not found for this material.

2. In 301 AISI austenitic stainless steel at total deformation $\varepsilon_{\text {tot }}=0.04-0.13$ and $\varepsilon_{\text {tot }}=0.14-0.68$, two long sections are found, which correspond to the stage of linear deformation. Stages of parabolic (Taylor) deformation hardening and predegradation are not found for this material.

3. For bimetal, the similar situation as for A 283 Grade low-carbon steel is observed sharp yield point and yield plateau with duration of 0.006 can be defined in the curve. In case of total deformation $\varepsilon_{\text {tot }}=0.09-0,20$ it is possible to define the stage of parabolic (Taylor) deformation hardening with total duration of $\varepsilon_{\text {tot }}$ $=0.11$. Stage of linear deformation hardening and predegradation is not found for this material.

As a result of mechanical tensile tests, the following mechanical properties were obtained: $\sigma_{0,2}-$ conventional yield strength, MPa; $\sigma_{B}$ - tensile strength, MPa; $\delta$ - specific tensile elongation, \% (Table 1).

According to the analysis of load deformations, plastic deformation in a bimetal sample is localized in the area of base material of A 283 Grade in the form of Chernov-Lüders band.

Chernov-Lüders band formed near the mobile grip is limited by a pair of fronts moved in opposite directions along the axis of the sample (Fig. 2) at different velocities $\pm \mathrm{V}_{\mathrm{f}}$. Front (1) moves in the direction of mobile grip and disappears after passing by a short section while front (2) continues moving in the ditection of fixed grip. If total deformation is $\varepsilon_{\text {tot }}=0.012$, another front of Chernov-Lüders band (front (3)) is formed in the area of fixed grip. Fronts (2) and (3) move towards each other, and when total deformation becomes equal to $\varepsilon_{\text {tot }}=0.015$, they meet and disappear. 


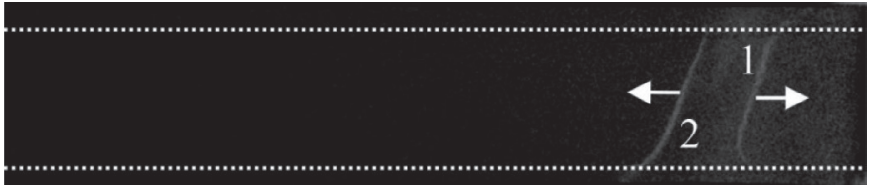

a)

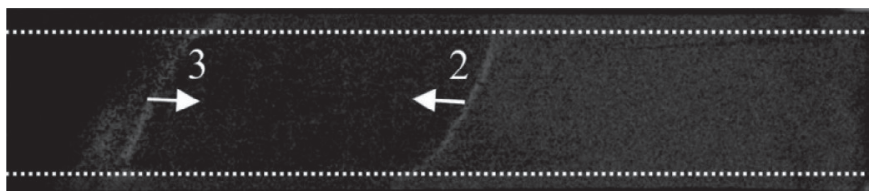

b)

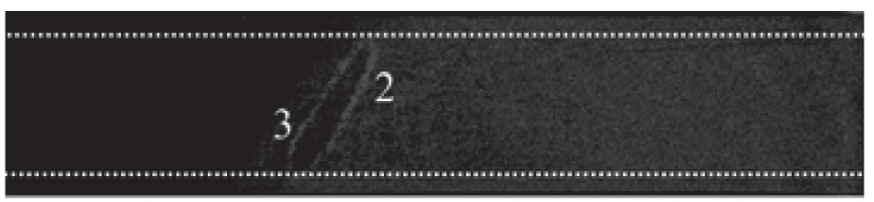

$7 \mathrm{~mm}$

c)

Fig. 2. Propagation of Chernov-Lüders band at total deformation: a) 0.006, b) 0.013, c) 0.014

2. ábra A Chernov-Lüders szakasz elörehaladása képlékeny alakváltozás során: a) $0.006, b) 0.013, c) 0.014$

To study kinetics of macrolocalization pattern development, presentation of positions $\mathrm{X}$ of local elongation centers $\varepsilon_{\mathrm{xx}}$ in a sample was used as a function of total deformation time. Authors of [17] demonstrate that this approach allows determining the velocity of deformation centers movement $\mathrm{V}$ $=\mathrm{dX} / \mathrm{dt}$ using kinetic diagrams (Fig. 3).

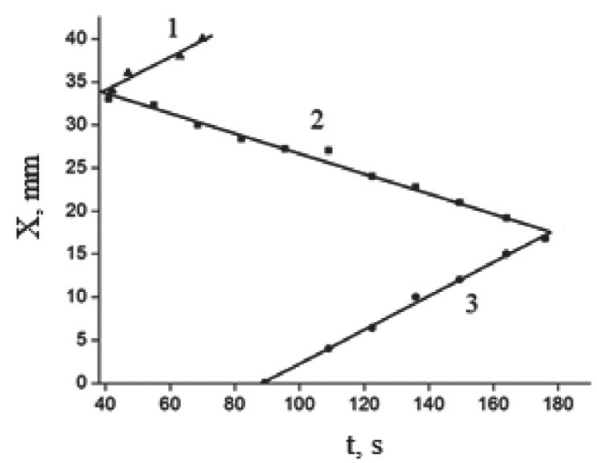

Fig. 3. Kinetic diagram of Chernov-Lüders band on the base layer of A 283 Grade material

3. ábra A Chernov-Lüders szakasz kinetikus diagramja A 283 minőségü anyag alaprétegében

Thus, velocities of Chernov-Lüders band propagation were measured in the base layer of A 283 Grade material. Propagation velocity of first two centers of Chernov-Lüders band occurred at the early stage of plastic deformation process is $\mathrm{V}_{1}=-1.9 \cdot 10^{-4} \mathrm{~m} / \mathrm{s}, \mathrm{V}_{2}=1.2 \cdot 10^{-4} \mathrm{~m} / \mathrm{s}$. Velocity of the third center of Chernov-Lüders band is $\mathrm{V}_{3}=-1.9 \cdot 10^{-4} \mathrm{~m} / \mathrm{s}$ (Fig. 3).

Since deformation is caused by complex resistance of bimetal to loading in comparison with its components, plastic flow is implemented by propagation of the front of Chernov-Lüders band in base soft metal at the initial stage. At the same time, solid cladding layer of stainless steel is elastically deformed. As a result only one front of Chernov-Lüders band is propagated in the upper cladding layer of 301 AISI material at the velocity of
$\mathrm{V}_{2}=2.4 \cdot 10^{-4} \mathrm{~m} / \mathrm{s}$. Two fronts of Chernov-Lüders band propagate in the lower cladding layer of 301 AISI material in the opposite directions at the velocities of $\mathrm{V}_{1}=0.7 \cdot 10^{-4} \mathrm{~m} / \mathrm{s}, \mathrm{V}_{2}=2.3 \cdot 10^{-4} \mathrm{~m} / \mathrm{s}$.

For comparison, the following was revealed during analysis of plastic deformation localization patterns for samples of $\mathrm{A}$ 283 Grade low-carbon steel and 301 AISI austenitic stainless steel during tension.

Occurrence of fronts of Chernov-Lüders band corresponds to stress of the upper sharp yield point in the diagram (Fig. 1). As a result, within the yield plateau, two fronts of ChernovLüders band are propagated towards each other at the velocity of $\mathrm{V}_{1}=0.6 \cdot 10^{-4} \mathrm{~m} / \mathrm{s}, \mathrm{V}_{2}=1.1 \cdot 10^{-4} \mathrm{~m} / \mathrm{s}$ (Fig. 4).

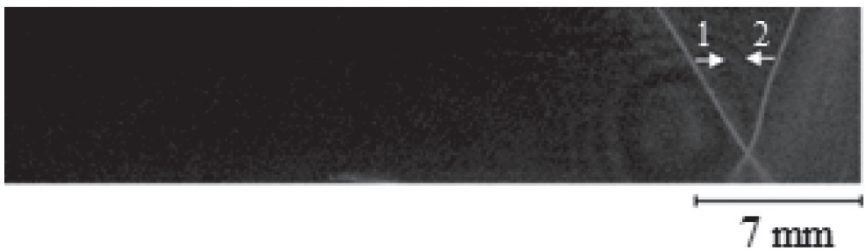

a)

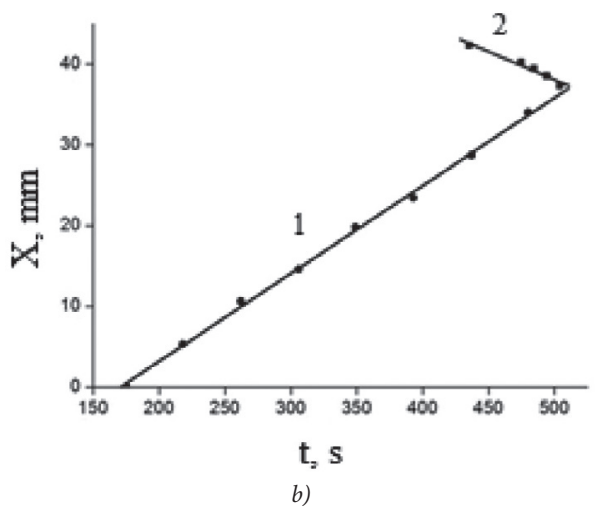

Fig. 4. Propagation of Chernov-Lüders band in 301 AISI material: a) visualization of Chernov-Lüders band propagation, b) kinetic diagram

4. ábra Chernov-Lüders szakasz elörehaladása 301 AISI anyagban: a) A ChernovLüders szakasz elörehaladásának megjelenitése, b) kinetikus diagram

At early stages of plastic deformation, the fronts of localized plastic deformation do not occur in austenitic stainless steel. At further stages of deformation, if total deformation is $\varepsilon=0.52$, $\varepsilon$ $=0.58, \varepsilon=0.62, \varepsilon=0.68$, four fronts, which move one after the other at velocities of $\mathrm{V}_{1}=2.1 \cdot 10^{-4} \mathrm{~m} / \mathrm{s}, \mathrm{V}_{2}=2.1 \cdot 10^{-4} \mathrm{~m} / \mathrm{s}, \mathrm{V}_{3}=1.7$. $10^{-4} \mathrm{~m} / \mathrm{s}, \mathrm{V}_{4}=1.3 \cdot 10^{-4} \mathrm{~m} / \mathrm{s}$ correspondingly, were revealed (Fig. 5).

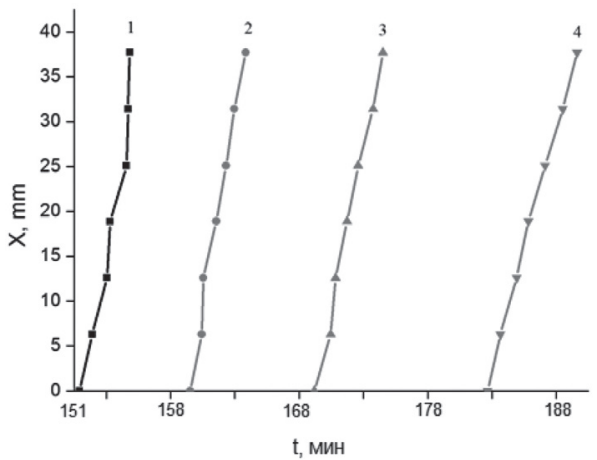

Fig. 5. Kinetic diagram of plastic deformation localization fronts propagation in 301 AISI austenitic stainless steel

5. ábra Képlékeny deformáció lokalizációs frontok kinetikus diagramja 301 AISI ausztenites rozsdamentes acél anyagban 
Process of material degradation starts with the localization of plastic deformation near structural heterogeneity and stress raisers [17] in the area of bonding of two dissimilar metals. At early stages of plastic deformation when total deformation is $\varepsilon$ $=0.24$, micro stress raisers are formed in the area of material bonding. These raisers contribute to formation of a localized area (Fig. 6), which is a prerequisite for neck formation in a sample and further degradation of material.
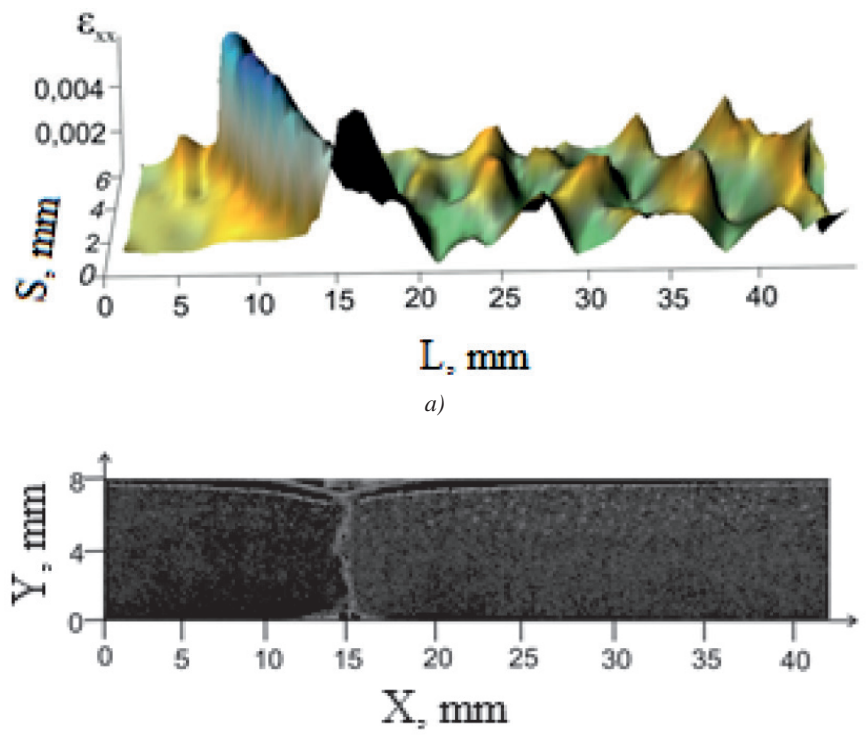

b)

Fig. 6. The picture of localized zones evolution deformation when total deformation is $\varepsilon=0.24$ (a); bimetal fracture (b)

6. ábra Lokalizációs frontok fejlődése $\varepsilon=0.24$ teljes deformáció esetén (a); bimetál törése (b)

\section{Conclusions}

The research conducted allowed formulation of the main laws of propagation of plastic deformation localization in a bimetal material and its component metals.

Analysis of localization patterns of plastic deformation showed that Chernov-Lüders band in the base A 283 Grade layer is limited with a pair of fronts moving in the opposite directions along the axis of bimetal at different velocities. Cladding layer of stainless steel $750 \mu \mathrm{m}$ thick: (1) causes the reduction of the yield plateau of bimetal; (2) does not suppress the occurrence of Chernov-Lüders band; (3) leads to increase in rates of propagation of Chernov-Lüders band fronts in the base layer and (4) decreases propagation of Chernov-Lüders band in all layers of bimetal.

Area of occurrence and development of a crack can be detected at early stages of strain hardening $8 \%$ prior to formation of a neck.

\section{Acknowledgements}

The work was supported by the Russian Science Foundation (project No. 16-19-10025).

\section{References}

[1] Zuev, L. B. - Barannikova, S. A. (2010): Plastic flow macrolocalization: autowaves and quasi-particles. Journal of Modern Physics. Vol. 1, pp.1-8. https://doi.org/10.4236/jmp.2010.11001
[2] Danilov, V. - Shlyakhova, G. - Semukhin, B. (2014): Plastic deformation macrolocalization. Local stresses and fracture in ultrafine grain titanium. Applied Mechanics and Materials. Vol. 682, pp. 351-356.

https://doi.org/10.4028/www.scientific.net/AMM.682.351

[3] Zuev, L. B. - Danilov, V. I. - Barannikova, S. A. - Gorbatenko, V. V. (2009): Autowave model of localized plastic flow of solids. Physics of Wave Phenomena. Vol. 17, pp.66-75.

https://doi.org/10.3103/S1541308X09010117

[4] Zuev, L. - Polyakov, S. - Gorbatenko, V. (2002): Instrumentation for speckle interferometry and techniques for investigating deformation and fracture. Proceedings of SPIE - The International Society for Optical Engineering. Vol. 4900, pp. 1197-1208. https://doi.org/10.1117/12.484526

[5] Barannikova, S. - Zuev, L. - Li, Y. (2018): Plastic flow heterogeneity and failure of bimetal material. International Journal of GEOMATE. Vol. 14, no. 43. pp. 112-117. https://doi.org/10.21660/2018.43.3578

[6] Zuev, L. (2017): Autowave processes of the localization of plastic flow in active media subjected to deformation. Physics of Metals and Metallography. Vol. 118, no. 8, pp. 810-819. https://doi.org/10.1134/S0031918X17060114

[7] Zuev, L. B. (2014): Using a crystal as universal generator of localized plastic flow autowaves. Bulletin of the Russian Academy of Sciences: Physics, Vol. 78, pp. 957-964. https://doi.org/10.3103/S1062873814100256

[8] Bell, J. F. (1973): Mechanics of Solids. The Experimental Foundations of Solid Mechanics, Springer. Berlin.

[9] Pelleg J. (2013): Mechanical Properties of Materials, Springer. Dordrecht.

[10] Hähner, P. (1994) Theory of solitary plastic waves. Journal of Applied Physics. Vol. A 58, pp. 41-58 (1994). https://doi.org/10.1007/BF00331515

[11] Srinivasan, N. - Raghu, N. - Venkatraman, B. (2012): Study on Lüders deformation in welded mild steel using infrared thermography and digital image correlation. Advanced Materials Research, Vol. 585, pp. 82-86. https://doi.org/10.4028/www.scientific.net/AMR.585.82

[12] Jiang, W. - Li, G. - Wu, Y. - Liu, X. - Fan, Z. (2018): Effect of heat treatment on bonding strength of aluminum/steel bimetal produced by a compound casting. Journal of Materials Processing Technology. Vol. 258, pp. 239-250. https://doi.org/10.1016/j.jmatprotec.2018.04.006

[13] Fu, B. - Qin, G. - Li, F. - Meng, X. - Zhang, J. - Wu, C. (2015): Friction stir welding process of dissimilar metals of 6061-T6aluminum alloy to AZ31B magnesium alloy. Journal of Materials Processing Technology. Vol. 218, pp. 38-47. https://doi.org/10.1016/j.jmatprotec.2014.11.039

[14] Jiang, Z. - Fan, Z. - Jiang, W. - Li, G. - Wu, Y. - Guan, F. - Jiang, H. (2018): Interfacial microstructures and mechanical properties of $\mathrm{Mg} / \mathrm{Al}$ bimetal produced by a novel liquid-liquid compound casting process. Journal of Materials Processing Technology. Vol. 261, pp. 149-158.

https://doi.org/10.1016/j.jmatprotec.2018.06.013

[15] Xiao, X. F. - Ye, S. P. - Yin, W. X. - Xue, Q. (2012): HCWCI/Carbon steel bimetal liner by liquid-liquid compound lost foam casting. Journal of Iron and Steel Research. Vol. 19, pp. 13-19.

https://doi.org/10.1016/S1006-706X(12)60145-9

[16] Li, Y. - Gong, M. - Wang, K. - Li, P. - Yang, X. - Tong, W. (2018): Diffusion behavior and mechanical properties of high chromium cast iron/low carbon steel bimetal. Materials Science and Engineering. Vol. 718, pp. 260-266. https://doi.org/10.1016/j.msea.2018.01.111

[17] Li, Yu. - Barannikova, S. - Shlyakhova, G. - Zuev, L. (2017): Investigation of structure and heterogeneity of the plastic deformation in bimetal exposed to uniaxial tension. AIP Conference Proceedings. Vol.1800, P. https://doi.org/10.1063/1.4973037

$\underline{\text { Ref.: }}$

Li, Yulia V. - Barannikova, Svetlana A. - Zuev, Lev B.: The localization of plastic deformation in bimetal Építőanyag - Journal of Silicate Based and Composite Materials, Vol. 70, No. 5 (2018), 168-171. p. https://doi.org/10.14382/epitoanyag-jsbcm.2018.30 